\title{
Organized Civil Society Under Authoritarian Populism: Cases from Ecuador
}

\author{
${ }^{1}$ University at Albany, SUNY, Albany, United States of America, E-mail: sappe@albany.edu \\ ${ }^{2}$ Universidad de Los Hemisferios, Quito, Ecuador, E-mail: danielb@uhemisferios.edu.ec \\ 3 Binghamton University, Binghamton, NY, USA, E-mail: ftelch1@binghamton.edu
}

\begin{abstract}
:
This article examines how civil society organizations (CSOs) in Latin America cope with authoritarian populism. In particular, it outlines cases of coping and adaptive strategies by CSOs in Ecuador during the years of President Rafael Correa's presidency (2007-2017). Ecuador provides an example of an authoritarian, leftist populist administration; thus situating our discussion in the general civil society-government relations literature, we link together trends of authoritarianism and populism and its implications on CSOs. Using a qualitativeinterpretive approach with long-term fieldwork in Ecuador, we outline a selection of coping strategies used by organized civil society that include formal, semi-formal and informal organizational configurations.
\end{abstract}

Keywords: nonprofit-government relations, civil society-government relations, populism, authoritarian regime, coping strategies, adaptive strategies, restrictive policies

DOI: 10.1515/npf-2019-0039

\section{Introduction}

This article examines the effects of authoritarian populism on civil society organizations (CSOs) in Latin America in the case of Ecuador. In particular, it outlines cases of coping and adaptive strategies by CSOs during the years of President Rafael Correa's presidency (2007-2017). We situate the Correa Administration as an authoritarian populist regime, as Ecuador experienced a combination of democratic practices with democratic deficits that led to authoritarian tendencies around political and civic liberties (see Croissant and Merkel 2004). As a case, Ecuador provides an experience that parallels several other contexts, in both the Global South and Global North, and offers learning for such contexts that are facing authoritarian regimes of many kinds and have consequences for CSOs.

The article proceeds as follows: First, in order to examine how CSOs cope with authoritarian regimes, we situate our discussion in the general civil society-government relations literature. We then outline the subset of authoritarian regimes that applies to the Ecuador case, namely left-wing populism. We briefly outline the global trends and leadership styles of populism in the Latin American context. The article then presents the case of Ecuador. We outline a selection of coping strategies used by organized civil society, as a spectrum that include formal, semi-formal and informal organizational configurations. The article contributes to understanding authoritarian hybrid regimes and the implications of authoritarian populism on organized civil society through an empirical case in Latin America.

\section{Civil Society-Government Relations in Twenty-first Century Authoritarian Populism}

Much research has contributed to scholarship about the policy environment for organized civil society (e. g. Appe and Barragán 2017; Appe and Marchesini da Costa 2016; Salamon and Toepler 2000; Irish, Kushen, and Simon 2004; Breen, Dunn, and Sidel 2016, 2019) and civil society-government relations more generally (e.g. Coston 1998; Najam 2000; Young 2000; Brinkerhoff 2002; Salamon 1995, 2002). Indeed, Najam (2000) stated that as CSOs " ... make their way through the policy stream, the goals, interests, priorities, resources, and other policy paraphernalia of the [CSOs] and of governments collide - sometimes in harmony, sometimes in discord" (p. 379). The Ecuador case builds onto this civil society-government literature. Some research has focused on the spectrum of relationships (e. g. Coston 1998). Scholars have found that often governments are reliant on CSOs,

Susan Appe is the corresponding author.

(c) BY (c) 2019 Appe, Barragán et al., published by De Gruyter

This work is licensed under the Creative Commons Attribution 4.o Public License. 
as they supplement the demands for public goods left unaddressed by government, or complementary as CSOs partner with government to deliver services (Young 2000). At times, CSOs have more adversarial relationships with government, pressuring for public policy changes and keeping government in check and accountable to the public (Najam 2000; Young 2000).

More recent research begun to focus on and address the statutory and non-statutory trends that affect organized civil society and what are called the "regulatory waves" that ebb and flow between the sectors (Breen, Dunn, and Sidel 2019). Within this research, contributing cases of authoritarian populist regimes becomes particularly important, as civil society-government relations appear to be different in this twenty-first century context. Before presenting the case of Ecuador, the following outlines the recent trends of authoritarianism and populism, particularly in Latin America.

\section{The Nexus of Authoritarianism and Populism in Latin America}

We use the term authoritarian populism in the case of Ecuador. We link together trends of an authoritarian regime and populism and the implications on organized civil society. Certainly in Latin America, we have several examples of what Weyland (2013) calls as "soft authoritarianism," "personalistic plebiscitarianism," and populism, both left leaning and right leaning, in countries that include Venezuela, Bolivia, Ecuador, Nicaragua, Honduras, Argentina and more recently Brazil. We concur that Latin America has seen a pattern of authoritarian populism, which can be described as "the sway of demagogic leaders who have accrued executive power, weakened pluralism and undermined effective institutional checks and balances" (Appe and Layton 2016, 11718).

The populism flavor of authoritarianism in Latin America denotes the specific communication style of its political actors who have challenged traditional power holders and elite values. While the Ecuador case presents a left leaning populism, ideologically, populism itself can link to so-called left or right governments (Canovan 1999). Populist leaders have extended widely worldwide, from not only populist governments in Latin America to other regions including leaders such as Vladimir Putin (Russia), Silvio Berlusconi (Italy), Recep Tayyip Erdoğan (Turkey) and even Bernie Sanders (U.S.). Extreme right movements have included Marine Le Pen in France and anti-Muslim movements in the Netherlands. Extreme left parties such as Beppe Grillo's five-star movement in Italy have surfaced.

Populism in its various shades, broadly includes: (a) a continuous exaltation to the people as a justification for behaviors and actions; (b) an anti-elitism feeling against those in power and (c) framing those who do not share their ideology as rivals or the others (Jagers and Walgrave 2007). Populist leaders communicate these features through stories, myths, and using direct language to project a collective dream (Budney 2011). Indeed, populist leaders are charismatic and aim to be recognized as legitimate representatives of 'the people' through the use of emotion. Populism cannot exist without the appeal to the people, establishing a considerable distance between the people and those elites that govern their interests (Deiwiks 2009). Even though there are common elements to populism, there are relevant differences in how economic, historical, ethnic, religious, demographic and political conditions play in the establishment of populist governments. As such, populism has been termed using many descriptors, such as revolutionary populism, intellectual populism, peasant populism, farmers' radicalism, populist dictatorship, populist democracy, reactionary populism, politician's populism, tecno populism, petro populism, among others (Canovan 1981; Deiwiks 2009; Mouzelis 1985).

In Latin America, we recognize three contemporary waves of populism in the region. The first wave, from 1940 to 1960, took place in Argentina and Brazil with leaders as Juan Domingo Peron (Argentina) and Getulio Vargas (Brazil), both of whom promoted a sense of belonging among classes and argued for a greater redistribution of resources to the poor. The second wave from 1990 to late 1990s involved the governments of Fernando Collor de Mello (Brazil) and Alberto Fujimori (Peru) and challenged the macroeconomic corrupt behavior of state-led elite groups and ended with the implementation of neoliberal reforms to foster economic growth. Finally, the third wave (from late 1990s to present) of populism in the region started first with the rise of Hugo Chaves in Venezuela, then Rafael Correa in Ecuador and Evo Morales in Bolivia. Identified as left-leaning populist leaders, they have opposed to free-market Western-oriented policies, the exploitation of their countries' commodities and committed to advocating for a more inclusive development model. Even though these movements are argued to be rooted in democratic principles, these governments have also been heavily criticized for authoritarian perspectives, corruption and violations to human rights, democracy and individual freedoms (Fisher 2017). ${ }^{1}$

In sum, the trends authoritarianism and populism globally spur new conceptual and empirical questions about the effects on organized civil society. In addressing civil society-government relations in this twenty-first century context, scholars have examined how authoritarian regimes in particular are approaching foreign aid funding and producing a 'shrinking space' for organized civil society, particularly for organizations working in human rights and democracy promotion (e. g. Carothers and Brechenmacher 2014; Dupuy, Prakash, and Ron 
2016; Dupuy and Prakash 2018). More recent empirical work has shown that regulatory measures - whether populist or other - have changed the composition and size of organized civil society (see the Ethiopian case, Dupuy, Ron, and Prakash 2015), and others propose that still further nuanced questions are warranted (e.g. Alscher el at., 2017; Anheier, Lang, and Toepler 2018). While previous work shows that some CSOs are "disappearing" and others "rebranding" their policy areas or programmatic functions (Dupuy, Ron, and Prakash 2015), the Ecuador case demonstrates, as our findings will show, the reconfiguration of organizational forms as coping and adaptive strategies to the changing institutional and operational space in which it occupies under an authoritarian populist government.

\section{Contribution and Research Approach}

Our research identifies strategies employed by organized civil society during a leftist, authoritarian populist regime in Ecuador. It is informed by years of in-depth fieldwork in Ecuador. We used qualitative-interpretive methods to explore on how subjects (civil society organizations) respond to events or ideas (government rhetoric and regulatory policies) (Yanow 2007). Data collection included government archival documents, media reports and documents produced by CSOs. The on-site fieldwork began in 2009 and included participation in dozens of meetings and informal conversations with civil society leaders as well as 88 in-depth, formal interviews with civil society leaders in Ecuador during the period of 2009-2016 (this took place during four stages of on-site data collection in 2009; 2010-2011; 2015; 2016). Three means for selecting the interviewed civil society leaders were used: a random selection of CSOs registered with government, a review of media reports to identify CSOs who were specifically affected by the new civil society regulations under Correa and continued snowball selection from interviewed CSOs.

Assisted by qualitative data software (HyperRESEARCH), we coded and sorted data into themes that further describe and explain CSOs' coping strategies (Corbin and Strauss 2008). During data collection and analysis, we used the process of memo-ing as defined by Corbin and Strauss (2008) as "written records of analysis" (117) to develop concepts and clarifications while we coded and classified the data. We stored memos and gradually built on analytic ideas through these documents. The authors have all worked closely with CSOs in Latin America and two of the authors have years of working alongside organized civil society in Ecuador. The third author aided with data collection of documents and data analysis. All three authors coded data during various stages which allowed for regular inter-rater reliability checks throughout the analysis process. The illustrative cases in this article were purposively selected to provide examples of the variation of the responses put forth by organized civil society during the Correa Administration.

\section{Ecuador and Its Civil Society}

Ecuador is in the Andean Region of South America with a population of just over 16.5 million (UNDP 2016). It is rich in natural resources such as oil and metals, particularly in its Amazonian region. Ecuador is designated as a medium-high income country by the World Bank (2016) and as a high-human-developed country by the United Nations Development Program (2016), however, it faces challenges related to inequity, political instability and public sector corruption. Neoliberal reforms of the 1990s presented new social demands that pushed decentralization processes in many Latin American countries, including Ecuador, which transferred functions and responsibilities to not only municipalities but also, to an even greater extent, to CSOs (Brautigam and Segarra 2007; Cabrera and Vallejo 1997; World Bank ).

While CSOs' role in public policy spheres became more institutionalized in the 1990s, it had been relevant since in the beginning of the twentieth century with strong ties to the Catholic Church and elite society. The labor union movement emerged in the 1930s and by the 1950s, development projects and programming began to integrate CSOs. Through relationships with the Catholic Church, organized civil society worked in rural technical assistance, disability services, family planning, and education (World Bank 2007). After decades of dictatorships, in 1979, Ecuador shifted to democracy while also facing an economic crisis (Brautigam and Segarra 2007). Under democracy, state-funded social programs were cut and economic reforms were implemented (Brautigam and Segarra 2007). As a result, Ecuador's civil society sector grew substantially in the 1980s and 1990s while it was fully integrated into the public policy process through service provision (Brautigam and Segarra 2007; World Bank 2007). This soon coupled with new organizations that were focused on "new social movements" related to environment, women, and indigenous projects (World Bank 2007). In the late 1990s, civil society was highly involved in contesting the state as the Ecuadorian government started to lose legiti- 
macy. Mistrust of public institutions grew and CSOs became key players in the ousting of three presidents ${ }^{2}$ (Brautigam and Segarra 2007).

However, still in Ecuador, CSOs have often failed to penetrate into national level policy debates. Ecuador's most recent 2008 Constitution attempts to address these democracy and participation deficits. Drafted in the beginning of Correa's Administration, the Constitution presented promising directions. It recognizes CSOs as a critical means of strengthening citizenship (Articles 96 and 97) and proposes an alternative framework of development called buen vivir, which has gotten international attention (Appe 2015; Villalba 2013). However, in terms of other institutional and legal frameworks, there is no specific overarching law which addresses organized civil society and its legal framework. Most regulation and rulemaking have been largely through executive decrees (Estupiñán 2008).

\section{Correa's Authoritarian Populism: Informal and Formal Tactics Targeting CSOs}

The leadership style of authoritarian populism includes charismatic, direct discourse and an authoritarian approach to power. Populist politicians share a particular way of appealing to the masses, by attacking the establishment and ruling elites. In Latin America, this has taken shape in the figure of el caudillo or the Latin American populist strongman. The style seeks the othering of elites - including, in the case of Ecuador, CSOs - and to seduce working class coalitions and politicians. Rafael Correa, as a populist leader, frequently expressed his distaste for the elite and the media, questioned the freedom of expression, and negatively portrayed the critics of his government (Hidalgo 2016). He used Twitter and Facebook as powerful tools to publicize these messages and to debate with his opponents. His social media accounts became regular channels to connect directly with followers, emphasizing his outsider status and viral rhetoric to followers and media (Wofford 2016). Social media was a tool that allowed for his communication and to produce further "othering", targeting the elite and the media, and identifying himself as being for the people (see Table 1).

Table 1: Correa's authoritarian populist leadership: illustrative examples.

\begin{tabular}{|c|c|}
\hline Topic/Target & Correa \\
\hline The people & The homeland returns \\
\hline The people & $\begin{array}{l}\text { End the "speech", despite the complicity of the press, the Ecuadorian people will demand } \\
\text { accountability ... (https://twitter.com/mashirafael/status/897875166381912064?lang=en) }\end{array}$ \\
\hline Othering & $\begin{array}{l}\text { There are clearly NGOs that come to create disturbances, that they finance ... terrible } \\
\text { interference of 'gringuitos' that want to impose in our country what they have never achieved } \\
\text { in their countries (El Ciudadano 2010). }\end{array}$ \\
\hline Elite & $\begin{array}{l}\text { They will continue with this avalanche of slander to camouflage their own incapacity and the } \\
\text { delivery of the country the same as always } \\
\text { (https://twitter.com/MashiRafael/status/897874945832833028) }\end{array}$ \\
\hline Media & $\begin{array}{l}\text { The vanity and double standards of the corrupt press and its lackeys: freedom of expression is } \\
\text { only for them (FundaMedios 2016). }\end{array}$ \\
\hline Media/CSOs & $\begin{array}{l}\text { "I am sorry Fundamedios [a media rights CSOs], but I'm going to have to block you. My } \\
\text { stomach does not give so much. 'Hello to your friends'3" (FundaMedios 2016) }\end{array}$ \\
\hline
\end{tabular}

During his presidency, Correa described organized civil society and CSOs using the descriptor "NGOs" in a disparaging way, a term he associated with neoliberalism (Appe, 2016). To complement the rhetoric, the Ecuadorian government began to release major regulatory policy reforms in several sectors including communication and media industries, higher education and organized civil society. In 2008, the Presidential Executive Decree No. 982 was released to revise the process for CSO legalization (See Table 2). This included a minimum amount of assets required for legal status and registration in a newly created online Registry of Civil Society Organizations (Presidencia 2008). An organization was required to present its documents to the line ministry that corresponds to its policy area so that it could verify that the organization was both active and was paying taxes to Ecuador's Internal Revenue Service. Thereafter the organization was to enter into the registry which was a centralized database that keeps record of these legally recognized CSOs and makes this information publicly available (Presidencia 2008) ${ }^{4}$. 
Table 2: Decrees targeting organized civil society during the Correa administration.

\begin{tabular}{ll}
\hline Decree & New provisions for CSOs \\
\hline Decree No. 982, 2008 & Minimum financial requirements \\
& New online registration \\
& Registration with line ministries \\
Decree No. 16, 2013 & New online registration \\
Decree No. 739, 2015 & Possible dissolution for interfering with "security" and "peace" in Ecuador \\
\hline
\end{tabular}

This 2008 regulatory action was followed by continued government rhetoric. Correa threatened that Ecuador would refuse conditional international aid, projects that often funded CSOs, calling such aid as "imperialistic humanitarian" programming (Agencia EFE 2010). Correa spoke directly to the Ecuadorian people, cautioning them to be "careful" of CSOs, and highlighted the process of the "NGOization" 5 of organized civil society (Agencia EFE 2010). Threatening more regulatory action, Correa explained in 2010 that "the party is over, the fair of joy is over" for CSOs (Flores 2010). He denounced the fact that there are more than 50,000 organizations with legal status in Ecuador. At the time he stated: "This is part of the corruption that has occurred in the country, no one knows where they are, who they represent, nor do they inform the government" (La Prensa Latina 2010).

In 2013, Decree No. 16 replaced Decree No. 982, adding several new requirements for nonprofit legal status (Presidencia 2013). Decree No. 16 created a new online registry called Unified Information System of Social Organizations which sought to make the activities of CSOs more transparency. The Decree also included language, albeit vague, that stated the CSOs were forbidden to interfere with "security" and "peace" in Ecuador. CSOs risked dissolution if they participated in activities that were deemed as threatening the country's security and peace. In 2015, a third decree, Decree No. 739 was released which in addition to Decree No. 16 regulated organized civil society (Presidencia 2015). Decree No. 739 includes similar requirements included in the previous Decrees. And like the other Decrees it introduced yet another new registry, the Unified Information System of Social and Citizen Organizations, however it was never implemented fully. At the time, there was expected confusion in the application of the law as Decree No. 16 had not been repealed and resulted in both Decrees simultaneously being in effect.

The decrees were intended to set definitions of organizational structures in organized civil society, outline the legal obligations to register with the government and establish processes to be used by public officials in ministries. Under this environment, there were several implications for and responses by CSOs. Specific organizations were targeted, particularly CSOs that received international funding, and those groups that were environmentally focused or worked in the realm of civil and political rights (Appe, forthcoming). This included threats for closure, in some cases forcing closures and in one case an organization was forcibly dissolved, which will be a case explained further below. As a result, like civil society itself, the responses by CSOs in Ecuador were diverse and several of these have been outlined in the literature elsewhere (Appe, forthcoming). Here, we focus on coping and adaptive strategies that sought to change organizational forms of organized civil society.

\section{Civil Society in Ecuador Responds}

We home in on different organizational configurations taken by organized civil society in response to the Correa Administration's rhetoric and policy reforms.

\section{Formal Organizations: Ecuadorian Confederation of Civil Society Organizations}

The most formal of organizational strategies can be illustrated by what would become the Ecuadorian Confederation of Civil Society Organizations (CEOSC). Started by a subset of CSOs in Ecuador, it not only represents a formalized response but also demonstrates the independent, self-organization of the sector in Ecuador. These CSOs began to meet once the Correa Administration released its first Decree No. 982 in 2008. First a small group of nine organizations, which tended to be larger, professionalized CSOs often with foreign funding and working in the provision of services as well as conducting advocacy for environment issues and democracy promotion, questioned the intentions of the then new Correa Administration. The small group of organizations released a public document to highlight main concerns with Decree No. 982 which included excessive discretion in the 
dissolution of CSOs and excessive discretion in the demand of information that public officials could require of CSOs (Aportes Ciudadanos a las Regulaciones de las Organizaciones de la Sociedad Civil del Ecuador 2009).

Many of the leaders from the participating CSOs during these beginning stages believed that the at-firstinformal group of organizations could tackle larger and broader issues across organized civil society, one leader explains:

To start, I believe that because of ... the fragmented characteristic of the sector, it has been very difficult in Ecuador to find an element that unified us, an element around which to form a [group of organizations] (personal communication, February 2011)

An informal Collective of organizations, which would slowly grow to dozens of organizations, began to provide a space to unify the sector. The idea to formalize was discussed from the beginning, however, several of the organizations took the stance that formalization needed to arrive after both trust and collaboration had been established. This included several years of working together to create a common vision and engaging in several projects along the way. For example, in 2011 the Collective released its first collective accountability report. This was the first time that organizations collected and presented data and information as sector. Since this first collective accountability report, there have been three more following with a growing number of organizations participating (Collective 2011, 2012; Ecuadorian Confederation 2014, 2016).

As the Collective was building trust during the period from 2009 to 2013, rhetoric from government continued. Draft regulations were circulated and the Collective attempted to meet with public officials to discuss the regulation of civil society and its legal framework more broadly. Eventually, the Ecuadorian Confederation of Civil Society Organizations (CEOSC) would be formally created. Since its inception in 2013, the Confederation includes over $100 \mathrm{CSO}$ and has sought to improve the civil society legal framework and promote interaction among CSOs and government. The CEOSC's three main objectives are to consolidate the sector and make it more visible; to promote the sustainability of the sector; and to engage in stronger inter-sectorial relations and policy dialogue. One member explained:

What are the benefits of being part of the Confederation? It helps us to defend ourselves, [and] have a strong voice. (personal communication, August 2015)

Soon after the creation of the Confederation, the Decree No. 16 in 2013 was released and as the Confederation continued its work the Decree No. 739 was released in 2015, with little change from Decree No. 16. These Decrees continued to prompt concerns by the Confederation because they included the high level of discretion by public officials, for example, there was wide discretion held by public officials to dissolve organizations.

As part of its objectives, the Confederation is supporting the creation of other formal organizations throughout Ecuador. It is helping to foster federations at the sub-national level as a strategy to build civil society capacity at the local level. The coordinator of the Confederation's project, explained it as the following:

Building federations at the ground level will allow for civil society visibility and create solidarity among civil society. It will illuminate local civil society action to enable further decentralization of donor funding, and it will allow civil society to better defend itself under some of the restrictive policies. (personal communication, July 2016)

The Confederation and the federations hope to become important vehicles in which organized civil society can further define mobilization strategies at the local level and practice independent, self-organization.

\section{Semi-formal Organizational Structures: From Pachamama to Terra Mater}

As noted above, under Correa's Administration, environmental groups in particular were targeted. In some cases, this resulted in threats to close and in one case an actual closure of a CSO. CSOs facing threats and closures often responded publicly through media, international networks as well as appealing to domestic and international legal bodies. One case is that of Fundación Pachamama which is an organization that partnered with indigenous organizations in Ecuador to defend land rights since 1997. Fundación Pachamama illustrates an organization that would reconfigure, not into a formal organization like the Confederation, but rather a semi-formal organization, notarized with bylaws and a governance system by its members but without proper nonprofit legal status.

Before the reconfiguration, in 2012 Pachamama supported the Confederation of Indigenous Nationalities of Ecuador (CONAIE) which organized protests in order to protect indigenous lands. As written about elsewhere, a Pachamama leader explains: 
Pachamama became an 'uncomfortable actor' [for government]. We worked with the CONAIE and others who were clearly against oil extraction. Pachamama was not an organizer but there was some protest disruption, verbal insults to the Chilean Ambassador, Juan Pablo Lira, and physical aggression to the business person of the Belorusneft [oil] company, Andrei Nikonkov. (personal communication, July 2016; see Appe, forthcoming)

Indeed, Fundación Pachamama was accused by government of physically harassing the ambassador of Chile and others during an event about oil concessions. A Pachamama leader asserted that government was placing blame on Pachamama, and essentially that it was "blacklisted" (personal communication, July 2016). Correa's Administration used the 2013 Decree No. 16 and its provisions about disturbing security and peace to revoke the legal status of Fundación Pachamama. A Fundación Pachamama leader explained:

On December 14, 2013, ten to fifteen people came, dressed at civilians. There was no process rather they decided on Saturday to shut us down. We were removed from the office, and closure tape was put on our office. (personal communication, July 2016)

After the shutdown, a letter of solidarity was signed by over 131 organizations worldwide to request that the government allow for the operation of Fundación Pachamama. Correa's government never officially responded. Fundación Pachamama argued publicly that Decree No. 16 "[sought] to suppress [its] legitimate right to dissent" (as cited in World Movement for Democracy 2013). At the time, Pachamama unsuccessfully pursued all available legal options in Ecuador to regain legalization. It then brought its case to the Inter-American Commission of Human Rights for a hearing in 2014 and also explored bringing a case to the Inter-American Court of Human Rights.

Pachamama's response thereafter provides an example of organized civil society taking on new organizational forms. Pachamama's organizational objectives took shape in another form, as an entity that would call itself 'Terra Mater'. As explained by a Pachamama leader in 2016:

We are now organized in a different way and not under the Pachamama name, it is not a legalized nonprofit organization, it is more of an association, but dealing with the same themes. It has notarized statutes and reports to Internal Revenue Services but it does not have [nonprofit] legal status nor is it registered as a CSO in a line ministry (personal communication, July 2016).

Indeed, this became an option for organizations working in environmental and indigenous rights in particular, those that seemed to bear many of the burdens of Correa's authoritarian populism and policy reforms. However, this brought about new challenges that the Pachamama leader explained. Even if more organizations opt to abandon the typical legalized nonprofit form, these organizations often still seek international funding and donors tend to want to fund organizations with proper legal status (personal communication, July 2016). However, there is some indication that this is changing as several donor countries are rumored to have loosened up funding rules when needed in what they perceive to be restrictive contexts for CSOs (Carothers and Brechenmacher 2014).

\section{Informal Network: The YASunidos Movement}

On the other end of the spectrum from the Confederation, but yet another example of an alternative organizational configuration that is linked to environmental and indigenous rights, the YASunidos movement is a collective group created in 2013 in response to President Correa's announcement to end the Yasuí-ITT Initiative. Under the Yasuí-ITT Initiative started in 2007, the Ecuadorean government had committed indefinitely to leave about 846 million barrels of oil underground in the Yasuní ecological reserve to avoid environmental destruction, specifically the emission of 407 million metric tons of carbon dioxide into the atmosphere which would be produced by the burning of these fossil fuels. It is worth noting that in addition to providing more space for citizen participation, the 2008 Constitution also established Ecuador as the first country to provide rights to nature. Under the buen vivir framework, across four articles in the Constitution, nature "has the right to integral respect for its existence and for the maintenance and regeneration of its life cycles, structure, functions and evolutionary processes," as well as it has the right to be restored, to be protected by government, and to be enjoyed by communities and peoples (Constitution 2008).

For the creation of the Yasuí-ITT Initiative, the Ecuadorian government expected economic compensation from the international community for $50 \%$ of the estimated value the profits that would have been levied if this resource was to be exploited (about 350 million dollars annually). In addition to vast biodiversity, the Yasuí National Park is home to two indigenous communities which live in voluntary isolation (YASunidos 2014). The Yasuí-ITT Initiative was internationally recognized: 
Environmentalists held up the plan as a prototype for an exciting new paradigm, one that would reduce the burden of environmental preservation on poor countries as the world took the first steps toward a post-fossil-fuel era. Since then, proposals for 'Yasunízation' - as pay-to-preserve initiatives have come to be known - have proliferated around the world, from New Zealand (coal) to Nigeria (tar sands), Quebec (gas fracking), and Norway's Lofoten Islands (oil)"' (Clynes 2016).

However, in August 2013, when international funding came in slower than expected, Correa ended the program, claiming: "The world has failed" Ecuador (as cited in Clynes 2016).

Some speculate that the Decree No. 16 released in June of 2013 (used to close Pachamama) was timed just before the announcement to end the Yasuí-ITT Initiative in August 2013 in government's anticipation that organized civil society groups - particularly environmental and indigenous - were not going to quietly accept its end (Wilkinson 2015). Thus, as a coping strategy, the YASunidos movement was initiated and as a collective it allowed for civil society participation without a need for a formal organization. Its mission is "to protect and conserve Yasuní National Park and the rights of the indigenous tribes that live in the park in voluntary isolation" (Yasunidos 2014). The YASunidos movement organized and put together a petition to hold a national referendum about oil exploitation in Yasuni, which was promptly denied by the Correa Administration (Vidal 2016). The petition was denied based on several technicalities and the administration claimed that the majority of signatures were invalid, which the YASunidos movement vehemently negated. Meanwhile, Correa called participants of the Yasunidas movement "troublemakers," "false greenies," and "well-fed nutcases" (as cited in Clynes 2016). After the petition's denial, YASunidos denounced the violation of political rights to the Inter-American Commission on Human Rights (YASunidos 2014).

While its impact on environmental policies and reversing government action during the Correa Administration was limited, the YASunidos movement was successful in inciting social mobilization from the bottomup. Whereas much has been written about the NGO-ization of civil society, which includes the strategic professionalization of civil society organizing and the creation of more formal organizations (Alvarez 1999; Jad 2004), the example of the YASunidos movement captures what could be called SMO-ization (social movement organization-ization), which is considered to rely more on decentralized "network structure, politicization, [and] reliance on protest" (Della Porta 2018). It might serve well contexts like Ecuador given its high levels of self-censorship according to surveys (Latinobarómetro 2016). Faced with this, forming as a collective, without legal status, presented an alternative "in which the anonymity of the mass ... allows to overcome fear to express criticism, among other things. In criticism there is individual punishment, in protest no" (Latinobarómetro 2016, 29). Indeed, it allowed leaders and lead organizations to have some anonymity while confronting the Correa Administration. This SMO-ization allowed civil society action to continue even as CSOs were under heightened scrutiny by government.

\section{Discussion and Conclusion}

The case of Ecuador provides an opportunity to better understand approaches taken by organized civil society which sustained 10 years of government rhetoric and regulatory policy reform under an authoritarian populist administration. Given the shifts of civil society-government relations under new twenty-first century contexts, the case contributes to understanding how CSOs cope with both authoritarianism and populism. As an authoritative, populist leader, Correa engaged in heavy discourse against CSOs - using "othering" tactics, for example, claiming CSOs represented elite and foreign interests, and also put forth several new regulatory executive decrees. Coping strategies employed by CSOs were on an organizational spectrum: formal, semi-formal and informal (See Table 3). These illustrations of the three organizational adaptations by organized civil society in Ecuador are derived from data collected during extensive fieldwork since 2009 that included participation in dozens of meetings, informal conversations with CSOs as well as formal interviews with civil society leaders in Ecuador.

Table 3: Organizational configurations as coping strategies for civil society in Ecuador.

\begin{tabular}{lll}
\hline Strategy & Ecuador example & Description \\
\hline Formal organization & $\begin{array}{l}\text { Ecuadorian confederation of civil } \\
\text { society organizations }\end{array}$ & $\begin{array}{l}\text { Formalization and } \\
\text { self-organization of a collective of } \\
\text { professional CSOs }\end{array}$ \\
Semi-formal organization & From Pachamama to Terra Mater & $\begin{array}{l}\text { Notarized association } \\
\text { S }\end{array}$
\end{tabular}


We argue that the ways in which CSOs manipulated the organizational configurations suggest that civil society under authoritarian regimes might be able to stunt the absolute shrinking of civil society. CSOs in Ecuador learned quickly, as consistent with populist leadership, that the Correa Administration targeted specific policy areas that threatened its political agenda. For example, CSOs working in indigenous and environmental rights were particularly targeted. The Correa Administration targeted not only these policy areas generally, but also specific organizations themselves - with threats and, in Pachamama's case, a closure. Through the reconfiguration of organizational forms, the Ecuador case shows means in which organized civil society copes and adapts to the changing institutional and operational space in which it occupies.

Civil society-government relations remain dynamic even within authoritarian and populists contexts. Perhaps the adversarial perspective or emphasis on conflict among civil society and government (e. g. Najam 2000; Salamon 2002; Young 2000) and their counter theories that suggested that civil society-government relations are more cooperative and more focused on partnerships and alliances (Salamon 1995) do not clearly capture what is occurring in new contexts of authoritarian and populist regimes. More precisely, while civil societygovernment relations have been documented as changing and cyclical (Young 2000), so too is organized civil society itself. The use of formal (in the case of the Confederation), semi-formal (Pachamama to a non-registered association) and informal network (in the case of the YASunidos movement) configurations were effective strategies employed during the Correa Administration for some CSOs and policy areas. Coalition building and self-organization, creative alternatives, and even 'going under cover' through diffused social movements are strategies and tweaks to organizational configurations that may serve as strategies and adaptations for CSOs elsewhere.

Indeed, the transferability of lessons for CSOs in areas of the Global South and the Global North where there are authoritarian and populist regimes is needed. Learning from cases like Ecuador supports the idea that nonprofit studies can further develop analytically and empirically to challenge simplistic binaries about the North and the South. Several civil society scholars have argued for this type of learning. Lewis (1998) criticized that the field of nonprofit studies tends to examine nonprofit organizations in the "North" and the organizations in the "South" are considered to be covered in development studies, referring to this as "unhelpful binary thinking" (Lewis 2017, 327; see also Lewis 2014). Furthermore, we are questioning our assumptions that the transfer of "knowledge, technology, and expertise" (Lewis 2017, 327) is from the North to the South only (Lewis 2014). Indeed, the transferability of lessons out of the Global South in particular "can support efforts to counteract years of one-way travel and generate organizational and policy innovations" (Lewis 2017, 327). Our research positions CSOs' experiences with authoritarian populism and their coping strategies in the South, in this case Ecuador, as an opportunity to transfer and exchange information, providing assistance to CSOs more globally.

Still, there are limitations to the case study approach used here. First, coping strategies from Ecuador provide promising directions, but we do not suggest that they are possible in all contexts. For example, while Ecuador provides insight to left-leaning populism in Latin America, further research might assess the Ecuadorian case in comparison to more right-leaning populism that we are seeing in other contexts, and now again in Latin America with Brazil's 2018 election of far-right populist Jair Bolsonaro. This might allow us to understand better the many shades of the nexus of authoritarianism and populism and how these contexts are shaping civil society-government relations.

In sum, there are further empirical and normative questions about what we expect about civil societygovernment relations in the current times. Since Correa has left office, a new Administration in 2017 in Ecuador under President Lenin Moreno has begun and is described as having a more friendly stance toward organized civil society. Civil society-government relations in Ecuador therefore are recalibrating to a certain extent. In sum, we posit that by providing the Latin American perspective of (left-leaning) authoritarian populism namely Ecuador during the Correa Administration - we show that Ecuadorian CSOs have the capacity, knowledge and experiences to be a global resource for learning about authoritarian and populist regimes, their implications on organized civil society and how CSOs might respond.

\section{Epilogue}

In 2017, Lenin Moreno, once Correa's Vice President, took the Presidential office. President Moreno repealed Decrees No. 16 and No. 739, both of which released during Correa's Administration to regulate CSOs. These two Decrees were replaced by Decree No. 193 which seeks to "regulate, simplify and rationalize the requirements for the granting of legal personality to social organizations ... " (Presidencia 2017). Although most of the provisions 
are consistent with the previous Decrees, it eliminates, for example, causes of dissolution that were left at the discretion of government officials and removed the provisions about disturbing security and peace. In practice, the reopened dialogue among government and organized civil society is exemplified by the case of Pachamama Foundation. After four years of closure, the Ministry of the Environment under President Moreno restored its legal status on November 17,2017 as a result of conversations among the Foundation's leaders and the Ministry.

In 2018, the Ecuadorian National Assembly starting reviewing a draft of the "Law of Nonprofit Organizations" which seeks to revise and make clearer the regulation of CSOs. Even with the new of direction by government toward organized civil society, CSOs in Ecuador remain cautious. Moving from dialogue and proposals to concrete actions and mechanisms that provide an enabling environment for organized civil society has proven difficult in Ecuador. Many CSOs argue that the strengthening and promotion of organized civil society and its roles in the provision of public goods and services and as defenders of rights, is still of highest importance under Ecuador's current President Moreno today.

\section{Notes}

1 Most recently, the election of Brazil's Jair Bolsonaro in 2018 might represent a new wave in Latin America. The newly elected president distinguishes himself as a far-right populist (Phillips 2018).

2 Gustavo Noboa (January 22, 2000 - January 15, 2003); Lucio Gutiérrez (January 15, 2003 - April 20, 2005); and Alfredo Palacio (April 20 , 2005 - January 14, 2007).

3 "Hello to your friends" was written in English in the original Spanish tweet.

4 While out of the scope of this article, see (author citation) for the challenges that these administrative and internet-based requirements put on specific CSOs in Ecuador.

5 NGO-ization is defined as the strategic professionalization of civil society organizing (see Alvarez 1999; Jad 2004) and often used disparagingly.

\section{References}

Agencia EFE. 2010. “Correa: Algunas Organizaciones Sin Fines De Lucro Son En Verdad Organizaciones De Lucro Sin Fin.” Accessed from http://informe21.com/rafael-correa/correaalgunas-organizaciones-fines-lucro-son-verdad-organizaciones-lucro-fin.

Alscher, M., E. Priller, S. Ratka, and R. G. Strachwitz. 2017. The Space for Civil Society: Shrinking? Crowing? Changing? Berlin: Maecenata Institut für Philanthropie und Zivilgesellschaft.

Alvarez, S. E. 1999. “Advocating Feminism: The Latin American Feminist NGO ‘boom'." International Feminist Journal of Politics 1 (2): 183.

Anheier, H. K., M. Lang, and S. Toepler. 2018. “Civil Society in Times of Change.” Economics Discussion Papers, No 2018-80, Kiel Institute for the World Economy. http://www.economics-ejournal.org/economics/discussionpapers/2018-80.

Aportes Ciudadanos a las Regulaciones de las Organizaciones de la Sociedad Civil del Ecuador. 2009. Quito, Ecuador. August 3, 2009.

Appe, S. 2015. “A Civil Society Network's Response to Regulatory Policy in Post-Neoliberal Ecuador.” Community Development Journal 50 (4): 693-708.

Appe, S. 2016. "Shifting the Development Discourse: A Narrative of a Civil Society Network in Ecuador." The Journal of International Development 28 (5): 666-82.

Appe, S. Forthcoming. “Nonprofit Organizations as Interpretive Communities: Responses to Policy Reforms in Ecuador." Policy Studies. OnlineFirst.

Appe, S., and D. Barragán. 2017. "Policy Windows for CSOs in Latin America: Looking outside the Standard Legal and Regulatory Environments." VOLUNTAS 28 (4): 1812-31.

Appe, S., and M. D. Layton. 2016. “Covernment and the Nonprofit Sector in Latin America." Nonprofit Policy Forum 7 (2): 117-35.

Appe, S., and M. Marchesini Da Costa. 2016. "Waves of Nonprofit Regulation and Self-regulation in Latin America: Evidence and Trends from Brazil and Ecuador." In Regulatory Waves: Comparative Perspectives on State Regulation and Self-Regulation in the Nonprofit Sector, edited by O. Breen, A. Dunn, and M. Sidel, 154-75. New York, NY: Cambridge University Press.

Brautigam, D. A., and M. Segarra. 2007. “Difficult Partnerships: The World Bank, States, and NCOs.” Latin American Politics and Society 49 (4) $149-81$.

Breen, O., A. Dunn, and M. Sidel, eds. 2016. Regulatory Waves: Comparative Perspectives on State Regulation and Self-regulation in the Nonprofit Sector. New York, NY: Cambridge University Press.

Breen, O., A. Dunn, and M. Sidel. 2019. "Riding the Regulatory Wave: Reflections on Recent Explorations of the Statutory and Nonstatutory Nonprofit Regulatory Cycles in 16 Jurisdictions." Nonprofit and Voluntary Sector Quarterly. OnlineFirst.

Brinkerhoff, J. M. 2002. “Covernment-Nonprofit Partnership: A Defining Framework.” Public Administration and Development 22 (1): 19-30.

Budney, J. 2011. “What We Can Learn from Populism." Fuse Magazine 34 (2): 10.

Cabrera A. C., and E. P. Vallejo. 1997. El Mito al Debate: Las ONGs en Ecuador. Quito, Ecuador: Alya-Yala Editing.

Canovan, M. 1981. Populism. London: Junction Books.

Canovan, M. 1999. “Trust the People! Populism and the Two Faces of Democracy.” Political Studies 47 (1): 2-16.

Carothers, T., and S. Brechenmacher. 2014. Closing Space. Washington, DC: Carnegie Endowment for International Peace.

Clynes, T. 2016. “As Oil Companies Dig Into Yasuní National Park, Ecuadorians Are Fighting Back.” Audubon Magazine. 
Collective of COSs of Ecuador. 2012. "Informe Rendicion De Cuentas 2011 [report of Accountability 2011]." Accessed from http://rendircuentas.org/wp-content/uploads/2012/10/InformeOSC2011-1_ecuador.pdf.

Collective of CSOs of Ecuador. 2011. “Informe De Rendicón Colectiva De Cuentas 2010 [report of Collective Accountability 2010].” Document on file with the author.

Constitution of the Republic of Ecuador. 2008. "Unofficial Translation." Accessed February 27, 2010. http://pdba.georgetown.edu/Constitutions/Ecuador/englisho8.html.

Corbin, J., and A. Strauss. 2008. Basics of Qualitative Research, 3rd ed. Los Angeles, CA: Sage.

Coston, J. M. 1998. "A Model and Typology of Covernment-NCO Relationships." Nonprofit and Voluntary Sector Quarterly 27 (3): 358-82.

Croissant, A., and W. Merkel. 2004. “Introduction: Democratization in the Early twenty-First Century." Democratization 11 (5): 1-9.

Deiwiks, C. 2009. “Populism." Living Reviews in Democracy, 1.

Della Porta, D. 2018. "Innovations from Below: Civil Society beyond the Crisis." Keynote speaker at the International Society of Third-Sector Research. Amsterdam, July 10, 2018.

Dupuy, K., and A. Prakash. 2018. “Do Donors Reduce Bilateral Aid to Countries with Restrictive NGO Laws? A Panel Study, 1993-2012." Nonprofit and Voluntary Sector Quarterly 47 (1): 89-106.

Dupuy, K., A. Prakash, and J. Ron. 2016. “Hands off My Regime! Governments' Restrictions on Foreign Aid to Non-Covernmental Organizations in Poor and Middle-Income Countries." World Development 84: 299-311.

Dupuy, K., J. Ron, and A. Prakash. 2015. "Who Survived? Ethiopia's Regulatory Crackdown on Foreign-funded NCOs." Review of International Political Economy 22 (2): 419-56.

Ecuadorian Confederation of CSOs. 2014. “Informe Rendicion De Cuentas 2013-2014." http://confederacionecuatorianaosc.org/rendicionde-cuentas/.

Ecuadorian Confederation of CSOs. 2016. “Informe Rendicion De Cuentas 2015-2016.” http://confederacionecuatorianaosc.org/rendicionde-cuentas/.

El Ciudadano. 2010. “Secretaría De Pueblos Realizará El Primer Encuentro Nacional De ONG's." Accessed November 20, 2010 http://www.elciudadano.gov.ec/index.php?option=com_content\&view=article\&id=19187:secretaria-de-pueblos-realizara-el-primerencuentro-nacional-de-ongs\&catid=1:actualidad\&Itemid=42ONG.

Estupiñán, P. 2008. “Marco Legal Y Regulatorio De Las Actividades De Autofinanciamiento De Las Organizaciones De La Sociedad Civil En El Ecuador." Nonprofit Enterprise and Self-sustainability Team.

Fisher, M. 2017. “How Does Populism Turn Authoritarian? Venezuela Is a Case in Point." The New York Times.

Flores, R. 2010, May 29. “Cobierno Anuncia Depuracion De Organizaciones No Cubernamentales.” Hoy. Accessed December 20, 2010. http://www.hoy.com.ec/noticias-ecuador/gobierno-anuncia-depuracion-de-organizaciones-no-gubernamentales-410649.html.

FundaMedios. 2016. “Presidente Bloquea a Fundamedios En Twitter Disgustado Por Datos De Studio." http://www.fundamedios.org/alertas/presidente-bloquea-fundamedios-en-twitter-disgustado-por-datos-de-estudio/.

Hidalgo, C. 2016. “De Trump a Correa." Plan V. Ideas. Retrieved from http://www.planv.com.ec/ideas/ideas/trump-correa.

Irish, L. E., R. Kushen, and K. W. Simon. 2004. Cuidelines for Laws Affecting Civic Organizations. New York, NY: Open Society Institute.

Jad, I. 2004. "The NCO-isation of Arab Women's Movements." Institute of Development Studies Bulletin 35 (4): 38.

Jagers, J., and S. Walgrave. 2007. “Populism as Political Communication Style.” European Journal of Political Research 46 (3): 319-45.

La Prensa Latina. 2010. “Denuncia Rafael Correa La Existencia De Unas 50 Mil ONG En Ecuador." Accessed from http://www.aporrea.org/actualidad/n158261.html.

\section{Latinobarómetro. 2016. Informe 2016. Santiago Chile: Corporación Latinobarómetro.}

Lewis, D. 1998. Bridging the Gap?: The Parallel Universes of the Non-profit and Non-governmental Organisation Research Traditions and the Changing Context of Voluntary Action. London, UK: Centre for Civil Society, London School of Economics and Political Science.

Lewis, D. 2014. "Heading South: Time to Abandon the 'parallel Worlds' of International Non-Governmental Organization (NCO) and Domestic Third Sector Scholarship?" VOLUNTAS: International Journal of Voluntary and Nonprofit Organizations 25: 1132-50.

Lewis, D. 2017. “Should We Pay More Attention to South-North Learning? Human Service Organizations: Management, Leadership \& Covernance 41 (4): 327-31.

Mouzelis, N. 1985. “On the Concept of Populism: Populist and Clientelist Modes of Incorporation in Semi-peripheral Polities." Politics and Society 14 (3): 329

Najam, A. 2000. “The Four-C's of Third Sector-Covernment Relations: Cooperation, Confrontation, Complementarity, and Co-Option." Nonprofit Management \& Leadership 10 (4): 375-96.

Phillips, D. 2018. “Populist Leaders to Attend Jair Bolsonaro's Inauguration in Brazil.” The Cuardian. https://www.theguardian.com/world/2018/dec/31/jair-bolsonaro-inauguration-brazil-president-brasilia-populist-leaders.

Presidencia de la República del Ecuador. 2008. “Decree No. 982." Accessed July 24, 2016. http://decretos.presidencia.gob.ec/decretos.

Presidencia de la República del Ecuador. 2013. “Decree No. 16." Accessed July 24, 2016. http://decretos.presidencia.gob.ec/decretos.

Presidencia de la República del Ecuador. 2015. “Decree No. 739.” Accessed July 24, 2016. http://decretos.presidencia.gob.ec/decretos.

Presidencia de la República del Ecuador. 2017. “Decree No. 193." Accessed May 3, 2018. http://decretos.presidencia.gob.ec/decretos.

Salamon, L. M. 1995. Partners in Public Service: Government-nonprofit Relations in the Modern Welfare State. Baltimore, MD: Johns Hopkins University Press.

Salamon, L. M. 2002. The Tools of Covernment. New York: Oxford University Press.

Salamon, L. M., and S. Toepler. 2000. The Influence of the Legal Environment on the Development of the Nonprofit Sector. Baltimore, MD: John Hopkins Center for Civil Society Studies.

United Nations Development Program. 2016. "Human Development Report." UNDP. Accessed from http://hdr.undp.org/sites/default/files/2016_human_development_report.pdf.

Vidal, J. 2016. "Ecuador Drills for Oil on Edge of Pristine Rainforest in Yasuni." The Guardian.

https://www.theguardian.com/environment/2016/apr/04/ecuador-drills-for-oil-on-edge-of-pristine-rainforest-in-yasuni.

Villalba, U. 2013. “Buen Vivir Vs Development: A Paradigm Shift in the Andes?” Third World Quarterly 34 (8): 1427-42. 
Weyland, K. G. 2013. “The Threat from the Populist Left." Journal of Democracy 24 (3): 18-32.

Wilkinson, D. 2015. "Environmentalists under Siege in Ecuador." Foreign Affairs. https://www.foreignaffairs.com/articles/ecuador/2015-0827/ecuadors-authoritarian-drift.

Wofford, B. 2016. “Pinochet. Chavez. Trump?” Politico.

World Bank. 2016. “PIB per Cápita US\$ a Precios Actuales." Accessed from http://datos.bancomundial.org/indicador/NY.CDP.PCAP.CD.

World Movement for Democracy. 2013. “Ecuador Uses Presidential Decree Powers to Shut down Protesting NCO." Accessed from http://www.movedemocracy.org/alerts/ecuadoruses-presidential-decree-powers-shut-down-protesting-ngo.

Yanow, D. 2007. "Qualitative-interpretive Methods in Policy Research," in Handbook of Public Policy Analysis: Theory, Politics, and Methods, edited by F. Fisher, C. J. Miller, and M. S. Sidney, 405-15. New York: CRC Press Taylor \& Francis.

Yasunidos. 2014. Summary of the YASunidos Petition to the IACHR." Washington D.C. sitio.yasunidos.org/images/Summary_Comunication1.docx.

Young, D. R. 2000. “Alternative Models of Covernment-Nonprofit Sector Relations: Theoretical and International Perspectives." Nonprofit and Voluntary Sector Quarterly 29 (1): 149-72. 